* ITAT becimentation CG CER Y7 VOLUME 77

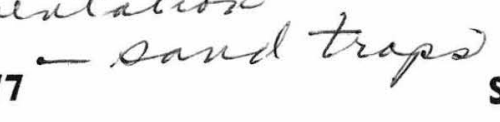

\title{
$M-12.28$
}

SEPARATE No. 67 copy 2
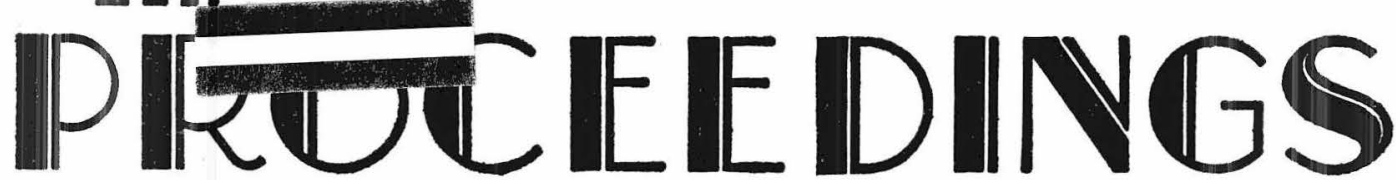

\section{AMERICAN SOCIETY \\ OF \\ CIVIL ENGINEERS}

MAY, 1951

MODEL AND PROTOTYPE STUDIES OF SAND TRAPS

By Ralph L. Parshall, Assoc. M. ASCE

IRRIGATION DIVISION

Copyright 1951 by the American Societr of Civil Exginfers Printed in the United States of America

Headquarters of the Society

33 W. 39th St.

New York 18, N.Y.

PRICE \$0.50 PER COPY 
The Society is not responsible for any statement made or opinion expressed in its publications

\section{H I N T S TO A U THORS}

Those who are planning papers for submission to PRoceEdngs will expedite Committee action measurably by first studying the standard instructions as to style, content, and format. For reprints, address the Manager,

Technical Publications, 33 W. 39th St.,

New York 18, N. Y.

Published at Prince and Lemon Streets, Lancaster, Pa., by the American Society of

Civil Engineers. Editorial and General Offices at 33 West Thirty-ninth Street,

New York 18, N. Y. Reprints from this publication may be made on condition that the full title of paper, name of author, page reference, and date of publication by the Society are given. 


\title{
AMERICAN SOCIETY OF CIVIL ENGINEERS
}

Founded November 5, 1852

\section{PAPERS}

\section{MODEL AND PROTOTYPE STUDIES OF SAND TRAPS}

\author{
By Ralph L. Parshall, ${ }^{1}$ Assoc. M. ASCE
}

\section{SyNOPSIS}

The deposition of water-borne gravel, sand, and silt has long been recognized as one of the most troublesome problems incident to the operation and maintenance of many of the irrigation and power canals of the West. Inordinate expenditures of time, labor, and money are made annually on this account. The reduction in the carrying capacity of a canal used for the delivery of water either for irrigation or for power means direct financial loss. In some cases periodic cleaning of the channels has resulted in such an accumulation that the spoil banks are approaching a limiting condition.

This problem has been investigated, primarily, at the Bellvue Hydraulic Laboratory at Fort Collins, Colo., by the Division of Irrigation and Water Conservation, Soil Conservation Service, United States Department of Agriculture, in cooperation with the Colorado Agricultural Experiment Station. From the investigations of various plans two practical methods have emerged to protect channels from bed-load deposits - the vortex tube and the riffle deflector, vortex-tube sand traps. They are capable of catching the bed load as it is moved along by the flowing water.

\section{The Vortex Tube}

The main feature of the vortex-tube sand trap, as shown in Fig. 1, is a tube with an opening along the top side, laid in the bottom of the channel at an angle of about $45^{\circ}$ to the axis of flow. The elevation of the top edge or lip is the same as the bottom or grade of the channel. As the water flows over the opening, a pronounced whirling or spiraled vortical motion is established within the tube; this motion extends throughout the tube length. This

Note.-Written comments are invited for publication; the last discussion should be submitted by October, 1951.

1 Collaborator, SCS, U. S. Dept. of Agriculture, Colorado Agric. \& Mech. College, Experiment Station, ort Collins, Colo. 
whirling action catches the bed load as it passes over the lip of the opening and carries the sediment to the outlet at the downstream end of the tube, where it is discharged into a suitable sluiceway for disposal.

Laboratory tests, as well as field tests, indicate that the optimum action of the vortex tube occurs when the water passing over the lip is moving at or near the critical velocity, that is, when the velocity head is equal to one half the depth of water at the lip of the tube. In the laboratory various shapes, sizes, and lengths of tubes were studied. For a particular setting of a 4-in. tube, with a water velocity of approximately $2 \frac{1}{2} \mathrm{ft}$ per sec over the lip and with $10 \%$ to $15 \%$ of the total flow wasted through the tube outlet, it was found

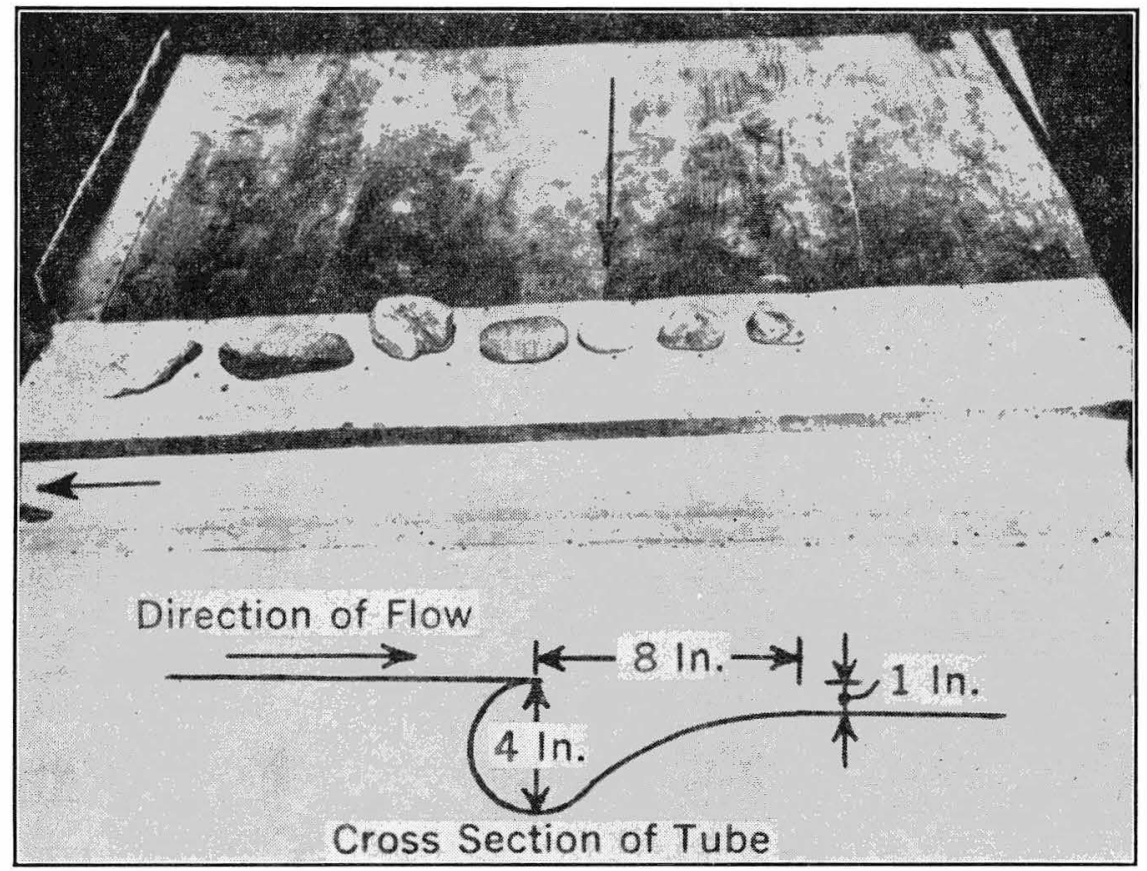

Fig. 1.-Four-Inch Tube Set $90^{\circ}$ to the Axis of the Channel

that the rate of rotation near the outlet was about $200 \mathrm{rpm}$. For this condition sand, heavy gravel, and stones as large as hens' eggs were readily ejected (see Fig. 1). Further investigations with a 4-in. tube of uniform diameter produced a maximum rotation of the spiraled flow of $300 \mathrm{rpm}$., which created sufficient energy to move a cobblestone weighing $7 \frac{1}{2} \mathrm{lb}$ along the tube at a uniform rate of about $\frac{1}{2} \mathrm{ft}$ per sec. The distance moved was about $7 \mathrm{ft}$, and the mean velocity of flow in the channel over the lip of the trap was $6.6 \mathrm{ft}$ per sec. The axis of the tube was at a $30^{\circ}$ angle to the axis of the channel and had a slope toward the outlet of $2 \mathrm{in}$. in $4 \mathrm{ft}$. Discharge of the tube was $3 \%$ of the total flow. When the 4-in. tube was set at an angle of $45^{\circ}$ to the channel with a velocity of flow of $6.9 \mathrm{ft}$ per sec, the maximum rate of rotation was 
$500 \mathrm{rpm}$, and enough energy was developed to transport cobblestones weighing from $3 \mathrm{lb}$ to $4 \mathrm{lb}$. Laboratory tests on a vortex tube indicated that the efficiency in diverting the bed load would be approximately $90 \%$. No particular success was attained in small-scale model studies of the vortex tube. Therefore, the laboratory work was confined largely to tube sizes ranging from 4 in. to 12 in. in diameter, which were assumed to be full-scale dimensions.

The vortex-tube sand trap has been tried in the field, and in some cases it has been a failure, whereas in other instances it has proved successful. Two conditions have been found to be awry in installations that have been ineffective: First, the velocity in the canal was too low, and, second, the tube

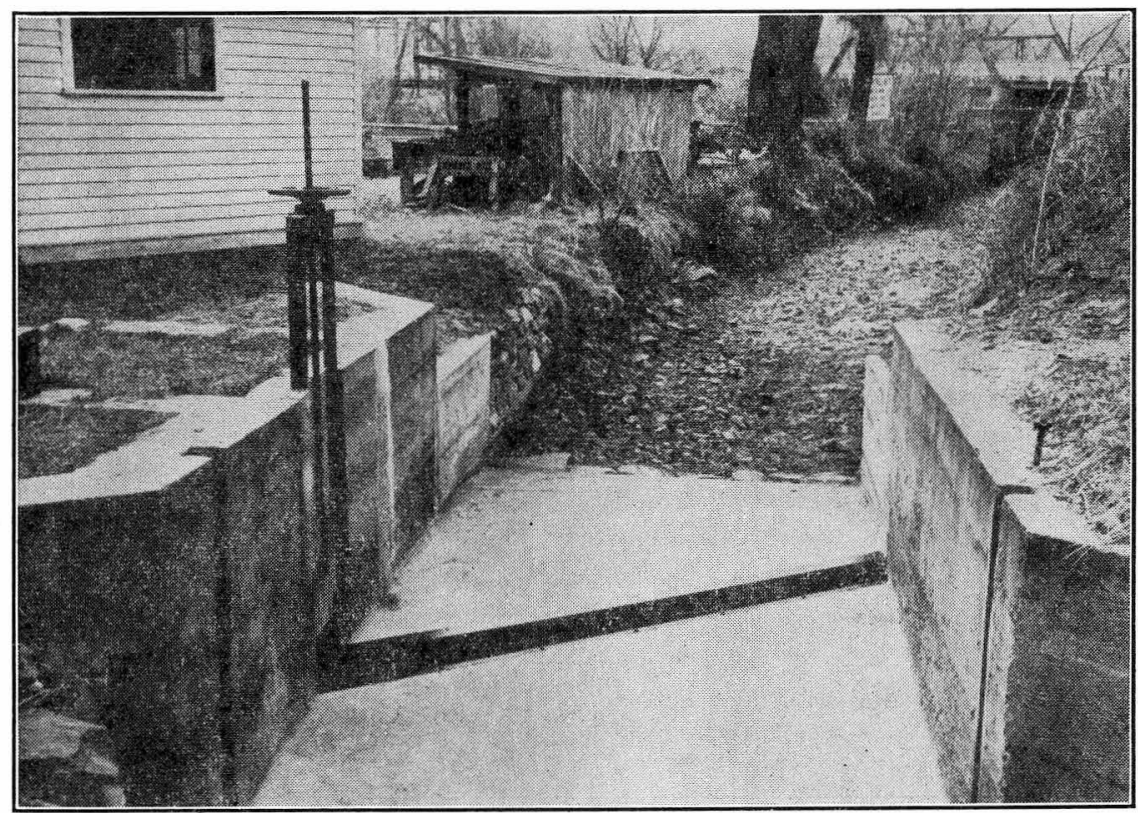

Fig. 2.-Vortex-Tube Sand Trap in Jackson Ditch, Bellyue Hydraulic Laboratory, Bellyue, Colo.

was set below grade in the channel. In the Jackson Ditch at the Bellvue Laboratory (shown in Fig. 2) a vortex tube has been in successful operation since April, 1935. The structure is of concrete, is $8 \mathrm{ft}$ wide, and has vertical walls and a channel rising slightly from the upstream end of the floor to the lip of the tube and sloping downward from the tube to the downstream end of the floor. The tube itself is cast of concrete and has a diameter at the outlet end of $8 \mathrm{in}$. and a back end diameter of $6 \mathrm{in}$. The tube is at an angle of $45^{\circ}$ to the axis of the channel. The capacity of the Jackson Ditch is approximately $60 \mathrm{cu} \mathrm{ft}$ per sec, and during periods of moderate to low river stage the diversion in the canal is $11 \mathrm{cu} \mathrm{ft}$ per sec. It appears that the tube is especially active at this minimum flow. No tests have been made on this particular 
installation, but evidence of the deposit accumulated at the end of the outlet indicates definitely that this sand trap is efficient.

\section{The Riffle-VAne Deflector}

The riffle-vane deflector sand trap consists of a series of curved sheet metal vanes. The plan view approximates a quadrant of a circle, and the side view is triangular in outline with the top point curved toward the downstream side, as shown in Fig. 3. The sheet metal vanes, 10 in. high and spaced about 10 in. apart, are attached in a vertical position to the smooth, level floor of a channel, and on some installations the floor is sloped laterally. Experiments were made with deflectors of various sizes, shapes, and spacing.

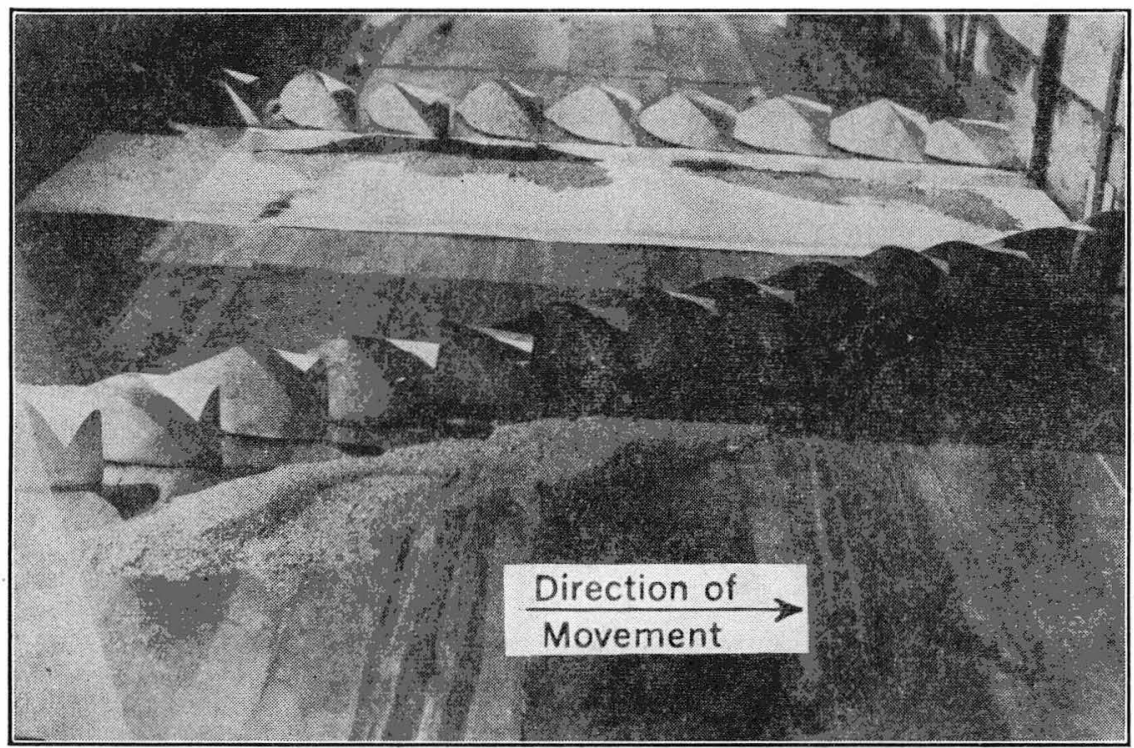

Fig. 3.-Experimental Riffl 9 Vanes Set at Angles of $90^{\circ}$ and $135^{\circ}$ with the Axis of an Eight-Foot Laboratory Channel

For some settings the action in moving the bed load was remarkably good. When the riffles were set in line normal to the axis of the canal, the bed load was moved laterally at $90^{\circ}$ toward the outlet in a well-defined, limited area immediately downstream from the line of riffles. The curvature of the riffle produced the effect which moved the load laterally, and the flow of water over the riffles resulted in a condition that maintained the bed load in a ridge downstream from the riffles. The action of the riffles was apparently independent of the depth of flow. Under maximum conditions of channel velocity (approximately $4 \mathrm{ft}$ per sec) the energy developed was sufficient to move large cobblestones, exceeding sizes which would pass through a 4 -in. square opening. 
Field tests have been made of this type of sand trap, but the device was not too successful. One of the disadvantages is that considerable debris lodges on the riffles, thus destroying the efficiency of the trap. One installation was made in the Wannamaker Ditch near Golden, Colo., where a series of six sets of riffles were placed in a channel $6 \mathrm{ft}$ wide. The riffles were 6 in. high. Observations made on this installation indicated that the sand removal under optimum conditions was about $15 \mathrm{lb}$ per sec. If the vanes are kept free of lodged material, such as roots, grass, tree branches, and other fibrous matter, this type of sand trap should be highly effective. The riffle-vane deflector sand trap is best suited for moderate channel velocities of $2 \mathrm{ft}$ to $3 \mathrm{ft}$ per sec. It is not intended for wide channels.

\section{The Riffle-Deflector Vortex Tube}

The most promising and practical sand trap developed is the riffle-deflector, vortex-tube type. In general, this device consists of a series of curved riffle deflectors on the bed of the channel. The bed load is moved laterally to the end of the riffles, where it is taken off through small vortex tubes discharging into a common compartment, as shown in Fig. 4. This compartment is provided with an outlet that sluices the total trap load back to the river, downstream from the diversion dam, or it is disposed of in basins as waste material. The riffles are parabolic in plan, have a vertical upstream face height of about $1 \frac{1}{2} \mathrm{ft}$, and a top surface sloping downward to a feather edge in a distance of about $5 \mathrm{ft}$ downstream, as measured parallel to the axis of the channel. A cross section of a single riffle is a right triangle. Since the riffles are curved identically in plan, they are fitted progressively, one against the other, in a downstream direction. The number of riffles depends on the nature of the bed load. For coarse sand and gravel fewer riffles would be required, whereas for fine sand the number of riffles would be greater-in no case probably exceeding a set of ten or twelve riffles.

This type of trap can be readily adapted to either narrow or wide channels and to flows ranging from less than $10 \mathrm{cu} \mathrm{ft}$ per sec to more than $2,000 \mathrm{cu} \mathrm{ft}$ per sec. For canals $20 \mathrm{ft}$ to $50 \mathrm{ft}$ wide it is suggested that two series of riffles be provided to crowd the bed load to the middle or axis of the channel. Short vortex tubes at the ends of the riffles carry the load into a narrow compartment built along the center line of the channel, where outlet pipe conducts the trapped sand and water to the point of disposal. For channels ranging in width from 50 to $100 \mathrm{ft}$ a double installation with four series of riffles is recommended. The outlets from the twin installation join in a common pipe placed below the bed of the canal, leading under the canal bank. Laboratory tests on models of the riffle-deflector, vortex-tube trap indicate that it is capable of capturing $90 \%$ or more of a weighed bed-load sample introduced in the approach channel upstream from the riffles.

A few field installations of this type of sand trap have been made, and all have been successful in catching bed loads, not only of relatively coarse material but also of fine sand. As an experimental installation of such a trap, a timber structure capable of handling very fine sand was built in the Sheep Creek Ditch near Torrington, Wyo. 
A reinforced concrete structure, placed in a supply canal for the Colorado Fuel and Iron Co. (Pueblo, Colo.), has a channel $40 \mathrm{ft}$ wide with a capacity of $250 \mathrm{cu} \mathrm{ft}$ per sec. It consists of two sets of riffles to move the bed load toward the center of the channel, where short vortex tubes pick it up and discharge it into a narrow longitudinal compartment. A 24-in. concrete pipe serves as an outlet from the downstream end of the compartment to the river. No tests have been made on this particular structure, but, after five years of

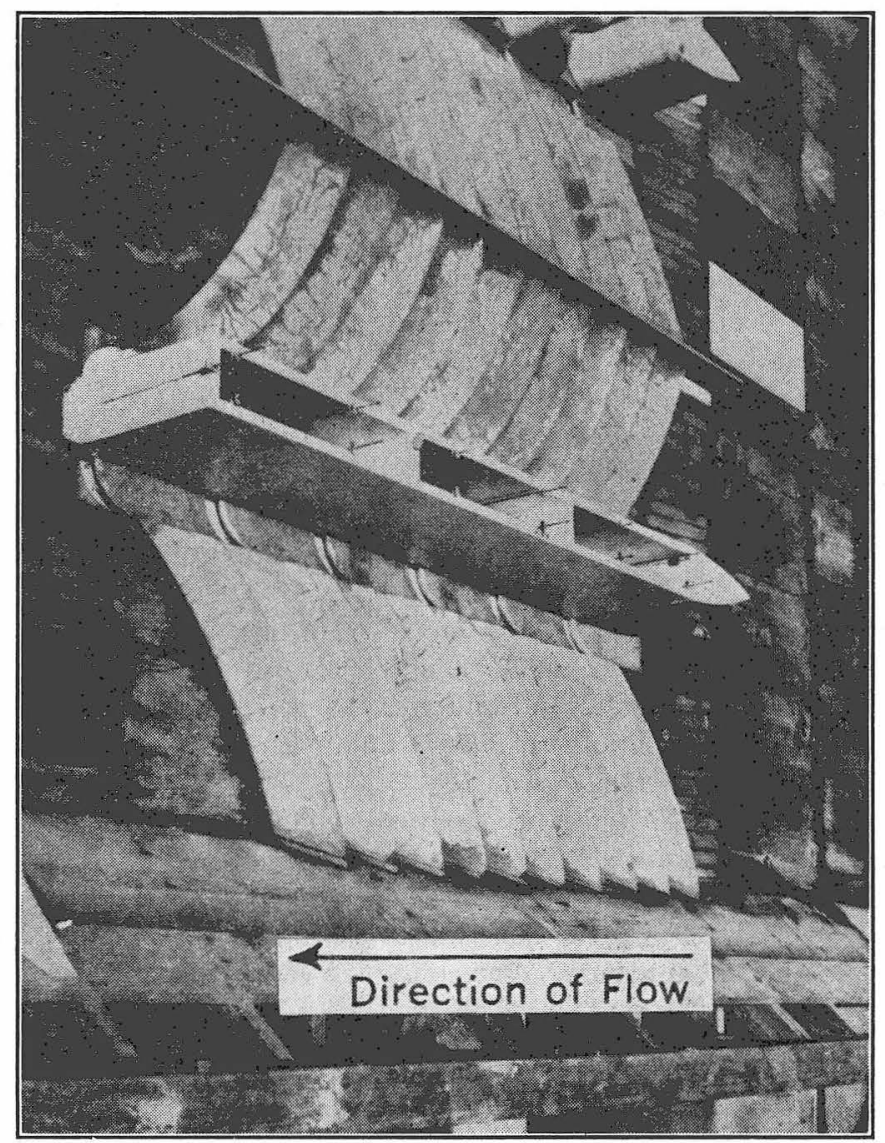

Fig. 4.-A Riffle-Deflector, Vortex-Tube Sand Trap

continuous use of the trap, observations along the canal downstream from the heading indicate that there is very little, if any, river sand found in the channel. It is assumed, therefore, that the efficiency of this installation is reasonably high.

Another problem requiring solution was the desanding of the Consolidated Irrigation District Canal that diverts from the King's River near Fresno, Calif. This canal has a bottom width of $90 \mathrm{ft}$ at the heading and a capacity of 
more than 2,000 cu ft per sec. Excessive cleaning operations resulted in great piles of sand at places along the canal, and in some instances the disposal piles encroached on vineyard lands that had to be purchased at $\$ 1,000$ per acre. Dragline cleaning was necessary at various points every season.

Because of the apparent success of the riffle-deflector, vortex-tube type of sand trap-especially the installation in the supply canal to the Colorado Fuel and Iron steel works - the Consolidated Irrigation District arranged for the building of a model at the Bellvue Hydraulic Lavoratory, where investigations and studies would be made of this type of trap.

\section{Model Studies of the Proposed Riffle-Deflector, Vortex-Tube Sand Trap}

This model was constructed of common $\frac{3}{4}$-in. surfaced lumber. It was $41 \mathrm{ft}$ long and occupied the full width of the 14 -ft laboratory channel. The model consisted of a double trap, of which both halves were identical except for the type of collection chambers. In one case a straight side-wall, sedimentstorage compartment was used. The compartment was $4 \mathrm{ft}$ wide inside and $62.5 \mathrm{ft}$ long with a streamlined upstream end to reduce turbulent flow over the riffles and the tubes. As an alternate design for comparison, the other half of the model was provided with six vertical 48-in. concrete pipe collectors spaced $10 \mathrm{ft}$ on centers and connected at the base by 24 -in. concrete pipes. A streamline splitter was fixed to the front side of the first vertical pipe. These two types of collection chambers were studied independently as to efficiency and were found to be equally satisfactory.

The sediment was deflected toward the central collection chamber by the riffle deflectors and was intercepted by a series of six vortex tubes, as shown in Fig. 4. The lips of the vortex tubes were $1.5 \mathrm{ft}$ below the grade of the channel. Because the first set of vortex tubes caught about two thirds of the total bed load and the first and second sets combined caught about four fifths of the total bed load, the outlet from each type of collection chamber was located at the point where the second set of vortex tubes discharged into the collection chamber. This required that the sediment from the vortex tubes farther downstream would have to move upstream in the collector, but the largest quantity of sediment would move a minimum distance in the collection chamber.

To gage the discharge through the model, a 40 -ft measuring flume, constructed to scaled dimensions, was placed downstream from the last riffles. For the prototype flow of 2,100 $\mathrm{cu} \mathrm{ft}$ per sec in the canal, the discharge of the 40- $\mathrm{ft}$ model flume was $6.64 \mathrm{cu} \mathrm{ft}$ per sec, and the discharge of the sedimentremoval system was $0.32 \mathrm{cu} \mathrm{ft}$ per sec. The canal discharge was regulated by means of flashboards, and the sediment discharge was regulated by slide valves at the outlet ends of the vortex tubes. The approach channel was 90 $\mathrm{ft}$ wide for a distance of $185 \mathrm{ft}$ with a scaled grade equal to that of the actual canal and side slopes of one to one.

Model testing, especially of sand-trapping devices, has never been very satisfactory because of difficulty in selecting the media used to simulate sand of various kinds and degrees of fineness. In these studies materials used 
included coarse and fine sand; silica, such as standard sand for cement briquette testing; pulverized soft and anthracite coals; pulverized hard pressed brick; soy beans; wheat; ground corn; and treated sawdust. Although it was not tried, it is believed that colored plastic material in suitable form would be found adaptable as a medium for model studies. For the Consolidated Irrigation District sand trap model actual sand from the canal, ordinary river sand obtained at the laboratory, and pulverized coal and brick were tried in the tests. Coal was found satisfactory for observing the action of the riffies and vortex tubes as well as the movement within the chambers toward the outlets. For the most part the discharge was for full capacity of the canal-about $2,100 \mathrm{cu} \mathrm{ft}$ per sec. The rate of flow in the channel was determined by measurement through the $40-\mathrm{ft}$ model flume, and the sediment

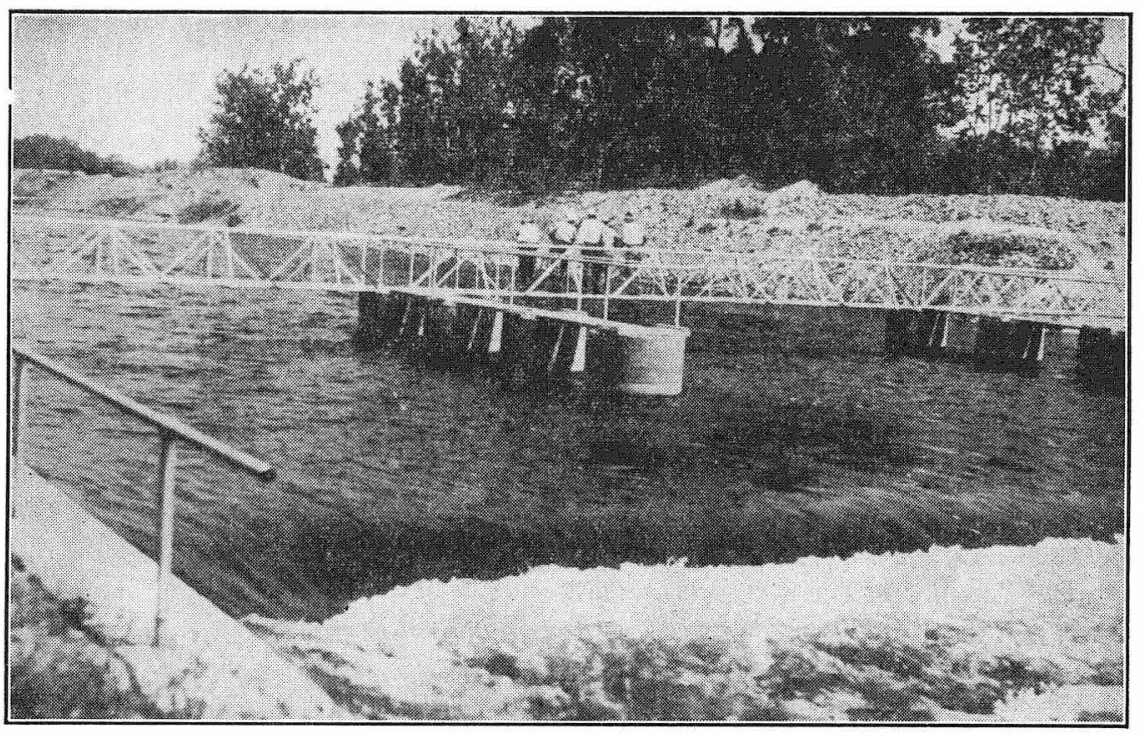

Fig. 5. Flow of 1,100 Cubic Feet per Second over the Weir, Looking Upgtream in the Canal. of the Consolidated Irrigation District

discharge was determined by a 3 -in. flume. The measured discharge over a 4-ft rectangular weir and the discharge through the $40-\mathrm{ft}$ model flume showed agreement within about $2 \%$.

The tests on the model were not extensive. Trial runs were made to permit visual observation of the general action of the riffles, of the tubes, and of the movement within the collecting chambers. Alterations in settings were made to prove the general over-all efficiency of the model.

Officials of the Irrigation District inspected the model in operation, and certain changes and alterations in design were discussed. In building the prototype, the primary change made to reduce costs was to eliminate the 40 -ft measuring flume and replace it with a low-crest weir across the canal immediately downstream from the sand trap structure. The 48-in. vertical 
concrete-pipe collecting wells were selected in lieu of the straight-walled compartment. Because of the relatively small percentage of bed load captured by the two downstream wells, it was decided to have four wells instead of six wells, as set up in the model.

Fer a flow of $1,788 \mathrm{cu}$ ft per sec over the control weir of the prototype, the mean velocity over the riffles was found by current meter observation to be $3.91 \mathrm{ft}$ per sec. For this canal discharge, the mean velocity of the model was computed to be approximately $3 \mathrm{ft}$ per sec, making a difference of about $1 \mathrm{ft}$ per sec. The canal section upstream from the sand trap, as shown in Fig. 5 . is straight, very uniform in width, and has a smooth cobble bed. The approaching flow, as indicated by the water surface, is smooth. Sand deposits on the bed of this section of the channel may have been present. If so, their presence was not indicated by boils at the water surface. Water was diverted uniformly into the canal through eight 10 -ft radial gates. The two outside gates were closed. For low flow (1,000 cu ft per sec or less) the mean velocities over the east, central, and west sections of the sand trap were definitely unbalanced. They were greater in the central section, as could be expected.

The efficiency of this large sand trap could be tested on a full scale in the field at considerable cost in time and money. Nevertheless, detailed observations of the canal at various distances downstream from the sand trap appear to indicate the effectiveness of this device. About one mile from the sand trap the main canal is divided into two branches. Just upstream from this bifurcation the canal is of considerable width with deep water at a relatively low velocity. Before the beginning of the 1949 irrigation season about April 1 st, this section of the canal was cleansed of sand deposit. At the close of the irrigation season, it was observed that very little sand had accumulated during the time the canal was in use. It is generally assumed by those who are closely associated with the operation of this large canal that the efficiency of the sand trap exceeds $75 \%$. Formerly, dragline cleaning operations were necessary each year, especially for certain stretches where the sand would deposit to a depth of $4 \mathrm{ft}$ or more per season. No cleaning was done during 1949. Sand in transit in the channels will move to places favorable for depositing and later will be dredged out. Once the system is stabilized, canal cleaning should be necessary only at three to five year intervals. It was estimated that the previous annual cleaning operations cost $\$ 4,000$ per year. The sand trap, which cost $\$ 15,000$, was completed December, 1947. 


\title{
AMERIGAN SOGIETY OF GIVIL ENGINEERS
}

\author{
OFFICERS FOR 1951
}

PRESIDENT

GAIL A. HATHAWAY

VICE-PRESIDENTS

Term expires January, 1952:

FRED C. SCOBEY

ALBERT HAER'TLEIN
Term expires October, 1952:

WILLIAM R. GLIDDEN

DANIEL V. TERRELL

\section{DIRECTORS}

\begin{tabular}{|c|c|c|}
\hline erm expires January, 1952: & anuary, 1958 : & $\begin{array}{c}\text { Term expires o } \\
\text { MILTON T. }\end{array}$ \\
\hline $\begin{array}{l}\text { ALDO G. BO } \\
\text { ORRIS GOOI }\end{array}$ & OTTO & ber, $195 \mathrm{~s}$ : \\
\hline AROLD L. BI & H. & \\
\hline L. $\mathrm{HOI}$ & $\begin{array}{ll}H O \\
\mathrm{H}\end{array}$ & $\mathrm{ACE}$ L. \\
\hline $\mathrm{FR}$ & J. R & N R. N \\
\hline S. T. HARDING & GEORGE W. LAMB & BURTON \\
\hline
\end{tabular}

\section{PAST-PRESIDENTS \\ Members of the Board}

FRANKLIN THOMAS

ERNEST E. HOWARD

TREASURER

CHARLES E. TROUT

EXECUTIVE SECRETARY

WILLIAM N. CAREY

E. L. CHANDIER

\section{PROCEEDINGS OF THE SOGIETY}

\author{
SYDNEY WILMOT \\ Manager of Technical Publications \\ HAROLD T. LARSEN \\ Editor of Technical Publications
}

COMMITTEE ON PUBLICATIONS

WALDO G. BOWMAN

FRANCIS S. FRIEL

S. T. HARDING
OTTO HOLDEN

LOUIS R. HOWSON

NORMAN R. MOORE 